\title{
When a large reserve is not large enough to protect part of a population: Blue-and-yellow Macaws (Ara ararauna) in central Brazil
}

\author{
Dárius Pukenis Tubelis \\ Departamento de Ciências Animais, Universidade Federal Rural do Semi-Árido, \\ Avenida Francisco Mota, 572, CEP 59625-900, Mossoró - RN, Brazil. \\ Author for correspondence \\ dtubelis@yahoo.com
}

\section{Resumo}

Quando uma extensa reserva não é grande o bastante para proteger parte de uma população: Araras-canindé (Ara ararauna) no Brasil central. Este estudo teve como objetivo examinar movimentos de araras-canindé (Ara ararauna) através de fronteiras entre o Parque Nacional das Emas e paisagens adjacentes, no Brasil central. Dois locais de estudo foram selecionados para observações conduzidas em outubro de 2006 e fevereiro de 2007. Grupos de araras foram observados deixando o parque e voando sobre extensas áreas agrícolas, em direção a remanescentes de vegetação nativa, evidenciando que estas aves utilizam recursos localizados na matriz de entorno da reserva. Estas observações sugerem que a conservação de parte da população de $A$. ararauna encontrada no Parque Nacional das Emas exigirá expansão desta reserva e/ou ações conservacionistas por fazendeiros da região.

Unitermos: fronteira, matriz, paisagem, Psittacidae, sistema de reserva

\section{Abstract}

This study aimed to examine movements of the Blue-and-yellow Macaw (Ara ararauna) across boundaries between the Parque Nacional das Emas and adjacent agricultural landscapes, in central Brazil. Two study sites were selected for observations conducted in October 2006 and February 2007. Groups of macaws were observed leaving the park and flying over extensive agricultural areas towards remnants of native vegetation, revealing resource use by these birds in the surrounding matrix. These observations suggest that conservation of part of the population of $A$. ararauna found at Emas National Park will require the expansion of this reserve and/or conservation actions by landowners in its surroundings.

Key words: boundary, landscape, matrix, Psittacidae, reserve system

The creation, protection and management of reserves is essential to the conservation of natural resources around the world (Caughley and Gunn, 1996; IUCN, 2003). Thus, the selection of priority areas for the establishment of reserves has occurred on all continents (Margules et al., 1988; Myers et al., 2000; Chan et al., 2004). The role of reserves in the conservation of regional biodiversity can be influenced by several 
factors, such as their sizes (Lindenmayer and Franklin, 2002; Primack, 2008). Thus, conservation plans often suggest that reserves should be as large as possible (Peres and Terborgh, 1995; Laurance, 2005).

In Brazil, a workshop has identified priority areas and actions for biodiversity conservation in the Cerrado, the vegetation province that dominates central South America (Cavalcanti, 1999; Cavalcanti and Joly, 2002). Among major recommendations were the creation of large reserves and the expansion of some conservation units already established. Despite broad agreement on the benefits of enlarging the size of reserves in the Cerrado (Cavalcanti, 1999), research on the values, advantages and needs of expansion of conservation units is lacking.

Even with the creation of huge ( $>500,000 \mathrm{ha})$ reserves during the 2000s (see Braz, 2003), the Parque Nacional das Emas is still one of the most extensive conservation units in the Cerrado (Silveira et al., 1999; Ramos-Neto and Pivello, 2000; França et al., 2007). Its current 132,000ha harbor a diverse range of native wildlife, including more than 300 bird species (Redford, 1985; Rodrigues et al., 2002; Braz, 2003; Batalha and Martins, 2007). Among outstanding aspects related to birds within this park are frequent flights of psitacid flocks through the mosaics of native physiognomies (personal communication) and across boundaries between the protected vegetation and the adjacent agricultural landscapes. For example, Blue-and-yellow Macaws (Ara ararauna) have been observed flying out of this reserve to forage in adjacent post-harvested soybean fields (Marsden and Wright, 2004). Despite the fact of being common, bird movements from reserves into adjacent productive landscapes have not been systematically investigated.

This study aimed to examine movements of $A$. ararauna across boundaries between Parque Nacional das Emas and adjacent agricultural landscapes. Results were discussed regarding the need of conservation actions around nature reserves in the Cerrado and other regions.

Field work was conducted along edges of Parque Nacional das Emas, a 132,000ha reserve in southwestern
Goias state, central Brazil. Elevations range from $720 \mathrm{~m}$ to $900 \mathrm{~m}$, and most of the park consists of flat tableland covered by grasslands and open woodlands (Ramos-Neto and Pivello, 2000; França et al., 2007). This park also harbors physiognomies such as riparian forests and wet grasslands with Mauritia palm trees (veredas). Fires are of common occurrence and can be natural or humaninduced (Ramos-Neto and Pivello, 2000; França et al., 2007). Climate is strongly seasonal and marked by well defined wet and dry seasons (Assad, 1994), with most of the annual precipitation (1,200 to $2,000 \mathrm{~mm})$ falling between October and March. The dry season occurs between May and September. Temperatures range from $0^{\circ} \mathrm{C}$ in July to $40^{\circ} \mathrm{C}$ in February (Assad, 1994). This reserve protects the headwaters of some hydrographic basins such as those of the Jacuba and Formoso rivers, and it is mostly surrounded by pastures and agricultural fields with soybean, cotton and corn (França et al., 2007). Further information on the environment in the Cerrado region can be found in Oliveira and Marquis (2002).

Observations were carried out at two study sites located in the northwestern portion of Parque Nacional das Emas (Figure 1). They were boundaries between protected native vegetation and adjacent agricultural fields. At Site 1, macaws were counted during late afternoons $(17: 00-18: 00 \mathrm{~h})$ on eight days between 1 and 12 October 2006. I counted macaws from a paved road that bordered the park. Sampling at Site 2 occurred during early mornings $(07: 30-08: 30 \mathrm{~h})$ on 12 days between 3 and 28 February 2007. At this site, I counted macaws from protected grasslands $100 \mathrm{~m}$ to $700 \mathrm{~m}$ from the park limits.

On a given morning or afternoon, all macaws flying out of the park were counted during a 40min sampling period. As they usually flew over $20-30 \mathrm{~m}$ above the ground, they could be easily detected. Macaws flying within a distance of $400 \mathrm{~m}$ on both sides of me were counted. The flat terrain around the two study sites and through the adjacent cultivated fields permitted the observation of macaws from great distances (near $1-2 \mathrm{~km}$ ), allowing me to discern the directions of movements. Thus, macaw records in this study represent long-distance movements across the reserve-plantation boundaries. 


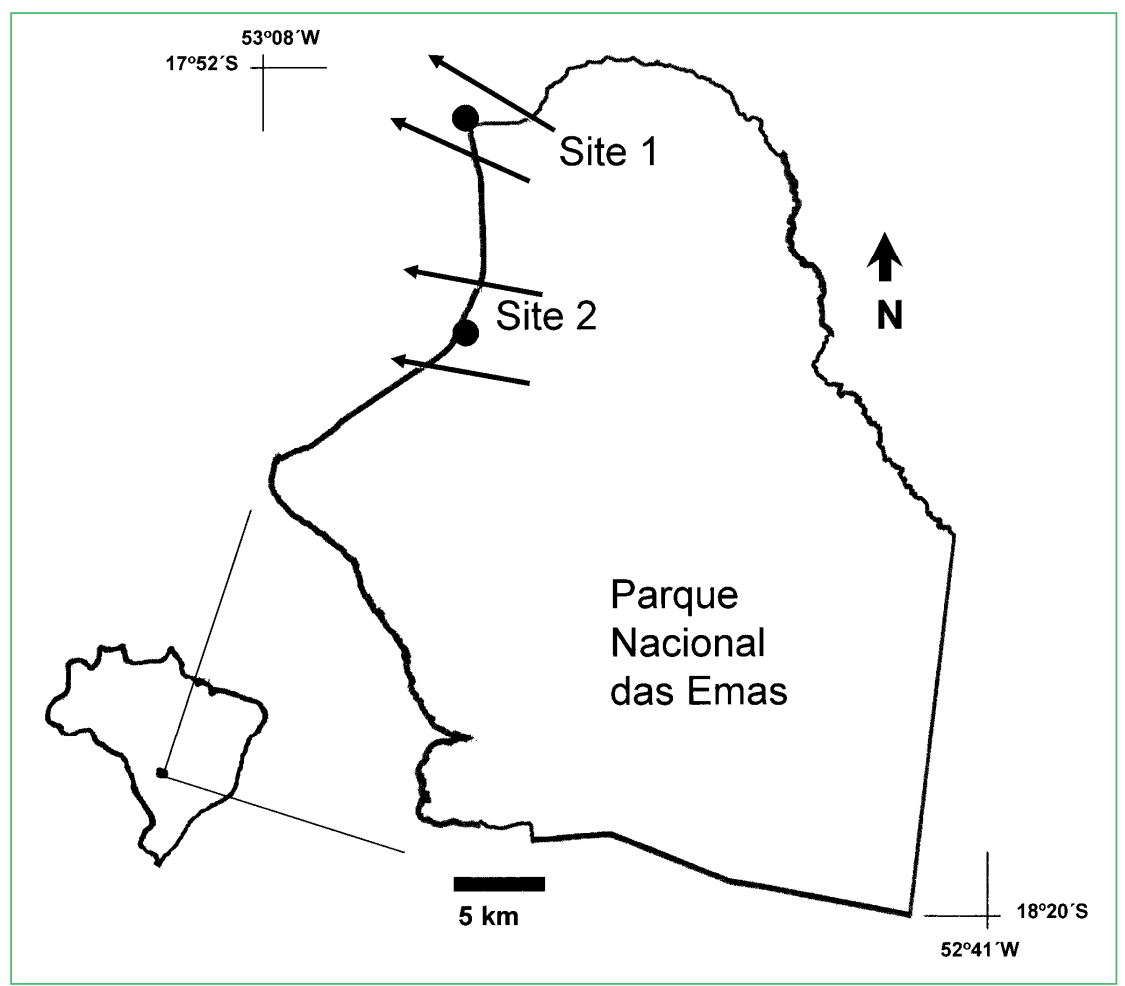

FIGURE 1: Parque Nacional das Emas in central Brazil, from where individuals of A. ararauna were recorded moving towards surrounding non-protected landscapes in October 2006 and February 2007. Arrows indicate the trajectories of flights at two study sites.

A total of 476 macaw records were obtained at site 1 . The numbers of macaws recorded per afternoon ranged from 44 to 72 (mean $=59.5 ; \mathrm{SD}=9.4)$. All birds crossed extensive tracts of bare ground and young soybean plantations and flew towards non-protected remnants located at $>2.5 \mathrm{~km}$ from the park limit. At site 2, a total of 223 macaw records were obtained. The numbers of macaws detected while crossing the park limits ranged between 12 and 29 (mean $=18.6 ; \mathrm{SD}=$ 5.3 ) on each morning. No macaws were seen landing on mature soybean plantations adjacent to the park. They were only seen flying over these exotic fields towards more distant areas.

Movements detected during afternoons suggest that numerous macaws leave Parque Nacional das Emas some minutes prior to sunset on a daily basis in October, after their nesting period. Thus, the roosting sites of several breeding pairs and young are located beyond extensive areas of cultivated fields adjacent to the park, although they could not be identified. Probably, macaws flew to remnants of veredas, their major nesting, foraging and roosting sites (del Hoyo et al., 1997; Bianchi, 1998), located within private properties at more than $3 \mathrm{~km}$ from this reserve. On two occasions in December 2008, I visited vereda remnants on two properties $4 \mathrm{~km}$ from the park boundaries and found several macaws coming from the direction of Parque Nacional das Emas late in the afternoons.

The records of movements during mornings in February suggests that some macaws that roost within Parque Nacional das Emas leave its protected areas to forage in non-protected landscapes, as some veredas located on private land are probably important foraging sites. Other landscape elements such as cerradão forests, grasslands and frequently burned woodlands also provide food resources for macaws (Juniper and Parr, 1998; Ragusa-Netto, 2006; Tubelis, 2009a, 2009b) and might attract them to non-protected landscapes around this reserve. In this region, food resources such as dry fruits attract numerous macaws to particular patches or remnants (Ragusa-Netto, 2006; Tubelis, 2009a). My records are different from those obtained by Marsden and 
Wright (2004) in soybean fields adjacent to the Parque Nacional das Emas. While I recorded no macaws landing on bare ground or on young or mature plantations, some foraging macaw aggregations were recorded in postharvested soybean fields in August by Marsden and Wright (2004). Macaws recorded by them came from the park and elsewhere.

Movements recorded in my study suggest that the home ranges of numerous $A$. ararauna found at Parque Nacional das Emas include native remnants in the surrounding non-protected landscapes. As a consequence, their survival in this Cerrado reserve will require conservation efforts outside its limits as well. This concern could also be directed to other parrot species. This is because numerous groups of the Redshouldered Macaw Diopsittaca nobilis, the Yellowfaced Amazon Alipiopsitta xanthops, the Blue-fronted Amazon Amazona aestiva and the Orange-winged Amazon Amazona amazonica were also seen flying towards non-protected landscapes during the 2007 sampling.

Long-distance flights have been detected for some macaw species in the Neotropical region. For example, groups of the Hyacinth Macaw Anodorhynchus hyacinthinus fly through extensive areas daily in the Brazilian Pantanal wetland (Guedes and Harper, 1995; Guedes, 2004). Flocks of the Lear' Macaw Anodorhynchus leari fly near $200 \mathrm{~km}$ on a daily basis between protected roosting areas and foraging sites in northeastern Brazil (Ibama, 2006). In the Atlantic Forest of south-eastern Brazil, some parrot species often move across boundaries between forest reserves and adjacent countryside (Marsden et al., 2000). In this Brazilian region, some macaws might use several forest fragments in addition to the major forest reserve (Evans et al., 2005; Nunes and Galetti, 2007). In the Brazilian Federal District, flocks of the Red-bellied Macaw Orthopsittaca manilata often leave nature reserves, sometimes to move to adjacent conservation units (personal communication).

Long-distance movements observed in these studies involved relatively small conservation units $(<30,000 \mathrm{ha})$. In contrast, my study highlights the fact that even big reserves might not be large enough to encompass the full range of requirements of several individuals of certain species, such as A. ararauna. Although some macaws might be able to survive exclusively within Parque Nacional das Emas, my study suggests that this large reserve is not sufficient for the protection of numerous individuals. Detailed studies of home ranges, demography and reproduction inside and outside Parque Nacional das Emas would be necessary to elucidate effects on $A$. ararauna regarding their movements over boundaries between protected and agricultural landscapes.

Reserve systems are not enough for the conservation of diverse ecological processes and regional species diversity, as reserves occupy only a small portion of ecosystems (Caughley and Gunn, 1996; Lindenmayer and Franklin, 2002). Thus, conservation efforts are necessary outside the reserve systems (Saunders et al., 1993; Hale and Lamb, 1997; Craig et al., 2000). My study suggests that even extensive reserves might require conservation efforts in their surroundings to better protect their biodiversity. In the case of the surroundings of Parque Nacional das Emas, conservation actions should ensure adequate protection of roosting and feeding sites of $A$. ararauna and other parrot species, particularly on private properties. Landowners could be educated or guided to protect these species by avoiding illegal capture and disturbances of their roosting and feeding sites. Also, they could receive supervision and benefits from governmental or non-governmental organizations to protect parrots and other wildlife on their land. Studies on home ranges would bring information on the extension of non-protected landscapes occupied by macaws found in Parque Nacional das Emas.

\section{Acknowledgements}

I thank IBAMA (especially Rogério O. Souza) for logistic support and a license to study wildlife at Parque Nacional das Emas. Mário B. Ramos Neto (CI-Brasil) kindly provided a map of the region. Dr. Stuart Marsden and two anonymous reviewers helped with references and suggestions. This study was financed by FAPESP (no. 05/00773-3), CNPq (no. 471360/2006-6), Idea Wild and the Neotropical Grassland Conservancy. 


\section{References}

Assad, E. D. 1994. Chuva nos cerrados. Análise e espacialização. Embrapa, Brasília, Brazil, 423pp.

Batalha, M. A.; Martins, F. R.. 2007. The vascular flora of the Cerrado in Emas National Park (central Brazil): a savanna flora summarized. Brazilian Archives of Biology and Technology, 50: 269-277.

Bianchi, C. A.. 1998. Biologia reprodutiva da arara-canindé (Ara ararauna, Psittacidae) no Parque Nacional das Emas, Goiás. Master's Dissertation, Universidade de Brasília, Brazil, 69pp.

Braz, V. S. 2003. A representatividade das unidades de conservação do Cerrado na preservação da avifauna. Master's Dissertation, Universidade de Brasília, Brazil, 70pp.

Caughley, G.; Gunn, A. 1996. Conservation biology in theory and practice. Blackwell Science, Cambridge, UK, 465pp.

Cavalcanti, R. B. 1999. Executive summary. Ações Prioritárias para Conservação da Biodiversidade do Cerrado e Pantanal. Funatura, Conservation International-Brazil, Fundação Biodiversitas and Universidade de Brasília, Brasília, Brazil, 24pp.

Cavalcanti, R. B.; Joly, C. A. 2002. Biodiversity and conservation priorities in the Cerrado region. In: Oliveira, P. S. \& Marquis, R. J. (Eds). The Cerrados of Brazil. Ecology and natural history of a neotropical savanna. Columbia University Press, New York, USA, p.351-367.

Chan, S.; Crosby, M. J.; Islam, M. Z.; Tordoff, A. W. 2004. Important bird areas in Asia. Key sites for conservation. BirdLife International, London, UK, 297pp.

Craig, J. L.; Mitchell, N.; Saunders, D. A. 2000. Conservation in production environments: Managing the matrix. Surrey Beatty \& Sons, Chipping Norton, Australia, 712pp.

del Hoyo, J.; Elliott, A.; Sargatal, J. 1997. Handbook of the birds of the world, v. 4, Sandgrouse to Cuckoos. Lynx Edicions, Barcelona, Spain, 679pp.

Evans, B. E. I.; Ashley, J.; Marsden, S. J. 2005. Abundance, habitat use, and movements of blue-winged Macaws (Primolius maracana) and other parrots in and around an Atlantic forest reserve. Wilson Bulletin, 117: 154-164.

França, H.; Ramos-Neto, M. B.; Setzer, A.. 2007. O fogo no Parque Nacional das Emas. Ministério do Meio Ambiente, Brasília, Brazil, 101pp.

Guedes, N. M. R. 2004. Management and conservation of the large macaws in the wild. Ornitologia Neotropical, 15: 279-283.

Guedes, N. M. R.; Harper, L. H. 1995. Hyacinth Macaws in the Pantanal. In: Abramson, J., Speer, B. L. \& Thomsen, J. B. (Eds). The Large Macaws: Their care, breeding and conservation. Raintree Publications, Fort Bragg, USA, p.394-421.

Hale, P.; Lamb, D. 1997. Conservation outside nature reserves. University of Queensland, Brisbane, Australia, 342pp.

Ibama. 2006. Plano de manejo da arara-azul-de-lear (Anodorhynchus leari). Ibama, Brasília, Brazil, 42pp.

IUCN. 2003. World parks congress 2003. Available at $<\mathrm{http}: / /$ www.iucn.org/wpc2003/index.htm>. Accessed on 15 December 2004.

Juniper, T.; Parr, M. 1998. A guide to the parrots of the world. Pica Press, Sussex, UK, 594pp.
Laurance, W. F. 2005. When bigger is better: The need of Amazonian mega-reserves. Trends in Ecology and Evolution, 20: 645-648.

Lindenmayer, D. B.; Franklin, J. F. 2002. Conserving forest biodiversity. A comprehensive multiscaled approach. Island Press, Washington, DC, 368pp.

Margules, C. R.; Nichols, A. O.; Pressey, R. L. 1988. Selecting networks of reserves to maximize biological diversity. Biological Conservation, 43: 63-76.

Marsden, S. J.; Whiffin, M.; Sadgrove, L.; Guimarães Jr, P. 2000. Parrot populations and habitat use in and around two lowland Atlantic forest reserves, Brazil. Biological Conservation, 96: 209217.

Marsden, S. J.; Wright, J. L. 2004. Blue-and-yellow Macaws feeding on soybeans in Brazil's cerrado zone. PsittaScene, 16: 15. Myers, N.; Mittermeier, R. A.; Mittermeier, C. G.; Fonseca, G. A. B.; Kent, J. 2000. Biodiversity hotspots for conservation priorities. Nature, 403: 853-858.

Oliveira, P. S.; Marquis, R. J. 2002. The Cerrados of Brazil. Ecology and natural history of a neotropical savanna. Columbia University Press, New York, New York, 398pp.

Nunes, M. F. C.; Galetti, M. 2007. Use of forest fragments by blue-winged macaws (Primolius maracana) within a fragmented landscape. Biodiversity and Conservation 16: 953-967.

Peres, C. A.; Terborgh, J. W. 1995. Amazonian nature reserves: An analysis of the defensibility status of existing conservation units and design criteria for the future. Conservation Biology, 9: 34-46.

Primack, R. B. 2008. A primer of conservation biology. Sinauer Associates Inc., Sunderland, USA, 292pp.

Ragusa-Netto, J. 2006. Dry fruits and the abundance of the Blueand-Yellow Macaw (Ara ararauna) at a cerrado remnant in central Brazil. Ornitologia Neotropical, 17: 491-500.

Ramos-Neto, M. B.; Pivello, V. R. 2000. Lightning fires in a Brazilian savanna national park: rethinking management strategies. Environment Management, 26: 675-684.

Redford, K. H. 1985. Emas National Park and the plight of the Brazilian cerrados. Oryx, 19: 210-214.

Rodrigues, F. H. G.; Silveira, L.; Jacomo, A. T.; Carmignotto, A. P.; Bezerra, A. M.; Coelho, D. C.; Garboggini, H.; Pagnozzi, J.; Hass, A.. 2002. Composição e caracterização da fauna de mamíferos do Parque Nacional das Emas, Goiás, Brasil. Revista Brasileira de Zoologia, 19: 589-600.

Saunders, D. A.; Hobbs, R. J.; Ehrlich, P. R. 1993. Reconstruction of fragmented ecosystems: global and regional perspectives. Surrey Beatty \& Sons, Chipping Norton, Australia, 684pp.

Silveira, L.; Jácomo, A. T. A.; Diniz Filho, J. A. F.; Rodrigues, F. H. G. 1999. Impact of wildfires on the megafauna of Emas National Park, central Brazil. Oryx, 33: 108-114.

Tubelis, D. P. 2009a. Feeding ecology of Ara ararauna (Aves, Psittacidae) at firebreaks in western Cerrado, Brazil. Biotemas, 22: 99-109.

Tubelis, D. P. 2009b. Bird foraging in Anacardium patches in central Brazilian firebreaks: relationship between flock size and patch size. Ornitologia Neotropical, 20: 421-430. 